\title{
Synthesis of FeNi Alloy Nanomaterials by Proteic Sol-Gel Method: Crystallographic, Morphological, and Magnetic Properties
}

\author{
Cássio Morilla dos Santos, ${ }^{1}$ Adanny Filipe Nogueira Martins, ${ }^{1}$ \\ Bruna Carolina Costa, ${ }^{2}$ Thiago Soares Ribeiro, ${ }^{3}$ Tiago Pinheiro Braga, ${ }^{4}$ \\ João Maria Soares, ${ }^{5}$ and José Marcos Sasaki ${ }^{1}$ \\ ${ }^{1}$ Laboratório de Raios X, Departamento de Física, Universidade Federal do Ceará, 60455-970 Fortaleza, CE, Brazil \\ ${ }^{2}$ Programa de Pós-Graduação em Ciência e Tecnologia de Materiais, Universidade Estadual Paulista, 17033-360 Bauru, SP, Brazil \\ ${ }^{3}$ Laboratório de Magnetismo e Materiais Magnéticos, Departamento de Engenharia Metalúrgica e de Materiais, \\ Universidade Federal do Ceará, 60440-554 Fortaleza, CE, Brazil \\ ${ }^{4}$ Laboratório de Peneiras Moleculares, Instituto de Química, Universidade Federal do Rio Grande do Norte, \\ 59078-970 Natal, RN, Brazil \\ ${ }^{5}$ Departamento de Física, Universidade do Estado do Rio Grande do Norte, 59625-620 Mossoró, RN, Brazil
}

Correspondence should be addressed to Cássio Morilla dos Santos; cmorillasantos@yahoo.com.br

Received 4 July 2016; Revised 24 October 2016; Accepted 27 October 2016

Academic Editor: Edward A. Payzant

Copyright (C) 2016 Cássio Morilla dos Santos et al. This is an open access article distributed under the Creative Commons Attribution License, which permits unrestricted use, distribution, and reproduction in any medium, provided the original work is properly cited.

\begin{abstract}
Proteic Sol-Gel method was used for the synthesis of FeNi alloy at different temperature conditions and flow reduction. The solids were characterized by XRD, $\mathrm{H}_{2}$-TPR, SEM, TEM, Mössbauer spectroscopy, and VSM. It was observed by X-ray diffraction pure FeNi alloy in the samples reduced at $600^{\circ} \mathrm{C}\left(40 \mathrm{~mL} / \mathrm{min}_{2}\right.$ flow $)$ and $700^{\circ} \mathrm{C}\left(25 \mathrm{~mL} / \mathrm{min}_{2}\right.$ flow $)$. The FeNi alloy presented stability against the oxidizing atmosphere up to $250^{\circ} \mathrm{C}$. The morphology exhibited agglomerates relatively spherical and particles in the range of 10-40 nm. Mössbauer spectroscopy showed the presence of disordered ferromagnetic FeNi alloy, and magnetic hysteresis loop revealed a typical behavior of soft magnetic material.
\end{abstract}

\section{Introduction}

In recent decades, many techniques have been employed for the synthesis of metallic alloys. In particular, those formed by iron and nickel have received attention, especially when they exhibit high values of permeability and saturation magnetization, as well as low coercivity. This material has been widely used in industrial activities for recording devices and transformers and in research as solid oxide fuel cells, alloys, and thin films [1-3].

An important consideration is that nanoparticle properties are extremely dependent on the domain size and may lead the material to exhibit soft magnetic behavior or superparamagnetism. In this sense, different techniques have been used for the synthesis of magnetic alloys, with gas evaporation $[4,5]$, physical methods $[1,6,7]$, coordinated coprecipitation [3], chemical reductions [8], and Sol-Gel methods [9]. The last mentioned technique encompasses relatively simple and inexpensive techniques, for example, the polymeric precursor method, which allows for obtaining pure and homogeneous nanomaterials at relatively lower temperatures.

Sol-Gel method is based on the hydrolysis and polycondensation reactions of alkoxide precursors. Moreover, the polymeric precursor method belonging to this group is one of the most cited in the literature. This method is based on the formation of a polymeric resin, produced in 
the polyesterification of metals chelated by a carboxylic acid and a polyalcohol [10-13]. Proteic Sol-Gel method can also be mentioned, which essentially makes use of an organic precursor in place of an alkoxide precursor. In this last synthesis method, some authors have used coconut water or gelatin for synthesis of nanoparticles and oxides due to the high concentration of proteins in its composition [14]. However, the literature lacks information about the synthesis and proprieties of FeNi alloys obtained by this procedure.

Gelatin gels are widely used in several areas including food, biological, chemical, pharmaceutical, and technical applications. An important property of gelatin is its ability to form a thermoreversible gel (physical gel) when cooled below $40^{\circ} \mathrm{C}$. In this case, a Sol-Gel transition can take place which leads to a progressive increase in its viscosity and elasticity. Moreover, the gel melts when heated and returns to liquid state. This is an advantage when compared with other techniques, since the gel is stable and can be stored for future use. Also, it has great biodegradability and biocompatibility, thereby being a good low cost reagent for chemical synthesis.

Proteic Sol-Gel method is an excellent alternative for the synthesis of nanometric alloys. Using edible bovine gelatin as the organic precursor, a study of FeNi alloy formation can be performed by varying parameters such as temperature and flow reduction. This method has already been used in recent studies for the synthesis of nickel ferrite and FeCo alloy, showing the potential of this method. However, optimizing variables using this synthetic process still have potential to be explored $[15,16]$.

The aim of this work was the synthesis of stable FeNi nanoparticles against oxidation by the proteic Sol-Gel method, using a rotary oven to improve sample homogeneity. Optimizing temperature reduction and hydrogen flow was sought to obtain a pure alloy formation. Furthermore, structure, morphological, and magnetic properties were compared with results obtained by other authors, in order to confirm the viability of the method and the quality of the synthesized samples.

\section{Materials and Methods}

The synthesis of the samples was performed by proteic Sol-Gel method [17] in order to obtain $1 \mathrm{~g}$ of FeNi alloy with a molar ratio of $1: 1$. For each synthesized sample, $17.64 \mathrm{~g}$ of $\mathrm{Fe}\left(\mathrm{NO}_{3}\right)_{3} \cdot 9 \mathrm{H}_{2} \mathrm{O}$ (Sigma-Aldrich) and $12.69 \mathrm{~g}$ $\mathrm{Ni}\left(\mathrm{NO}_{3}\right)_{2} \cdot 6 \mathrm{H}_{2} \mathrm{O}$ (Sigma-Aldrich) were dissolved in deionized water containing $30.33 \mathrm{~g}$ of edible bovine gelatin $\left(\right.$ Gelita $\left.^{\mathrm{TM}}\right)$. The dissolution occurred under constant stirring at $80^{\circ} \mathrm{C}$ to promote homogeneity of the solution. Subsequently after removing the solvent, the samples remained in an oven at $100^{\circ} \mathrm{C}$ for $48 \mathrm{~h}$ to form the xerogel. An initial sample was thermally analyzed to associate the mass loss with the thermal processes involved in the burning of the xerogel. For this, thermogravimetric (TG) and differential thermal analyses (DTA) were simultaneously obtained using a Shimadzu DTA$60 \mathrm{H}$, from 25 to $1000^{\circ} \mathrm{C}$ at a heating rate of $10^{\circ} \mathrm{C} / \mathrm{min}$ under air synthetic flow of $40 \mathrm{~mL} / \mathrm{min}$.
After obtaining the xerogel, the oxidation process was performed at $700^{\circ} \mathrm{C}$ for $120 \mathrm{~min}$ for the other samples with a heating rate of $10^{\circ} \mathrm{C} / \mathrm{min}$ and air flow of $30 \mathrm{~mL} / \mathrm{min}$ in a rotary oven operating at $18 \mathrm{RPM}$. In this stage of the study, an oxidized sample was analysed by temperature programmed reduction (TPR) to determine the temperature at which iron and nickel are reduced to a metallic state. About $30 \mathrm{mg}$ was analysed from 50 to $800^{\circ} \mathrm{C}$ in a quartz reactor using a thermal conductivity detector, flow of $25 \mathrm{~mL} / \mathrm{min}\left(8 \% \mathrm{H}_{2} / \mathrm{N}_{2}\right.$ mixture), and heating rate of $10^{\circ} \mathrm{C} / \mathrm{min}$.

Then, the synthesis conditions under study were divided into three sets of samples reduced at 500,600 , and $700^{\circ} \mathrm{C}$ for $60 \mathrm{~min}$, respectively. Once again, the process used a heating rate of $10^{\circ} \mathrm{C} / \mathrm{min}$ and a rotary oven operating at 18 RPM. A set of four samples was obtained for each abovementioned temperature, using hydrogen flows of 25, 30, 40, and $50 \mathrm{~mL} / \mathrm{min}$, respectively.

The crystallographic structures were determined by $\mathrm{X}$ ray diffraction (XRD) using a X-Pert PRO MPD Panalytical diffractometer for polycrystalline samples. Phase identification was performed through X-Pert HighScore Panalytical software and the JCPDS-ICDD 2003 database [18]. Additionally, Rietveld refinements were done using GSAS software [19] and EXPGUI interface [20], after determining instrumental broadening by means of refining a $\mathrm{LaB}_{6}$ NIST standard sample.

Morphology was observed by scanning electron microscopy (SEM-FEG) using a EVO LS15 Carl Zeiss with an energy dispersive X-ray spectrometer (EDS) from Oxford, INCA. Complementary particle sizes were estimated by transmission electron microscopy (TEM) using a JOEL JEM $2100 \mathrm{LaB}_{6}$ operating at an accelerating voltage equal to $200 \mathrm{kV}$ and equipped with a TV (Gatan ES500 W) and CCD (TVips $16 \mathrm{MP}$ ).

Fundamental information about the alloy was obtained by Mössbauer spectroscopy, carried out at room temperature using a ${ }^{57} \mathrm{Co}$ source in a rhodium matrix. The curves were deconvoluted using Normos-90 [21] and PC-Mos II [22] and a least-square fitting routine. Complementing the magnetic analysis, magnetic hysteresis loop was achieved by vibrating sample magnetometry (VSM) at room temperature, with an external magnetic field range between -12 and $12 \mathrm{kOe}$.

Finally, in order to determine the influence of rotary oven, two samples were reduced at $700^{\circ} \mathrm{C}$ with hydrogen flow of $30 \mathrm{~mL} / \mathrm{min}$. In this case, Williamson-Hall plot [23, 24] was employed to compare the microstructure of the samples obtained with and without rotation. In another experiment, thermal stability was estimated using a high temperature oven coupled to the diffractometer. In this case, diffractograms were collected immediately after the temperatures of 25, 100, 250,350 , and $450^{\circ} \mathrm{C}$ were reached, respectively.

\section{Results and Discussion}

Initially, analyses were performed to obtain data on the organic and inorganic material elimination during the first stage of calcinations and to determine optimal conditions for the synthesis of the samples. The thermal analysis is 


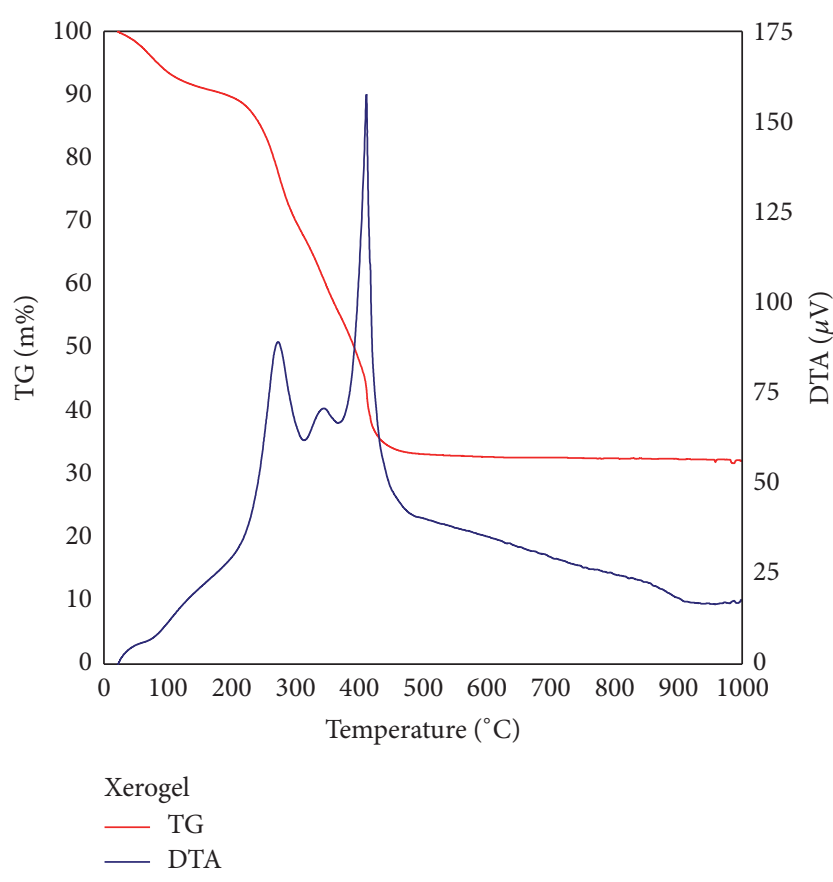

FIGURE 1: Thermogravimetric (TG) and differential thermal analyses (DTA) of xerogel.

shown in Figure 1; considering the TG curve, the analysis can be divided into two main events related to mass loss. From 25 to $150^{\circ} \mathrm{C}$, there was a loss of $8.1 \%$. This endothermic event, according to the DTA curve, originated from the water desorption process. The second event, between 155 and $505^{\circ} \mathrm{C}$ and mass loss of $56.1 \%$, is attributed to protein burning, nitrate decomposition, organic compound degradation from the oxidation process, and carbon monoxide and dioxide volatilization. These processes were characterized as exothermic events $[15,25]$. After $505^{\circ} \mathrm{C}$, there were no significant changes and the sample remained at $35.8 \%$ of the initial mass. Decomposition of the gelatin through calcinations is essential for obtaining small particles, since organic fraction acts hinder sintering of the inorganic portion during heat treatment and forms oxides containing iron and nickel.

In Figure 2, the peaks represent the temperatures at which iron and nickel were reduced to metallic state. It was observed that the reduction process was started at $260^{\circ} \mathrm{C}$, and the sample was completely reduced above $650^{\circ} \mathrm{C}$. Two reduction peaks can be clearly seen at 400.2 and $545.4^{\circ} \mathrm{C}$ and another possible peak around $430^{\circ} \mathrm{C}$, as marked in Figure 2. XRD measurements on samples obtained with different synthesis conditions explain the TPR analysis as follows: between 260 and $500^{\circ} \mathrm{C}$, the first peak $\left(400.2^{\circ} \mathrm{C}\right)$ is attributed to the reduction of iron oxidation state from +3 to +2 , considering nickel ferrite $\left(\mathrm{NiFe}_{2} \mathrm{O}_{4}\right)$ is present before the reductions. The shoulder $\left(430^{\circ} \mathrm{C}\right)$ is considered the reduction of nickel from valence +2 to metallic state. Moreover, the second peak $\left(545.4^{\circ} \mathrm{C}\right)$ is attributed to the reduction of iron to metallic state. The range in which the reduction of metals was observed complies with that observed for FeCo alloy, also obtained by proteic Sol-Gel method [15]. Importantly,

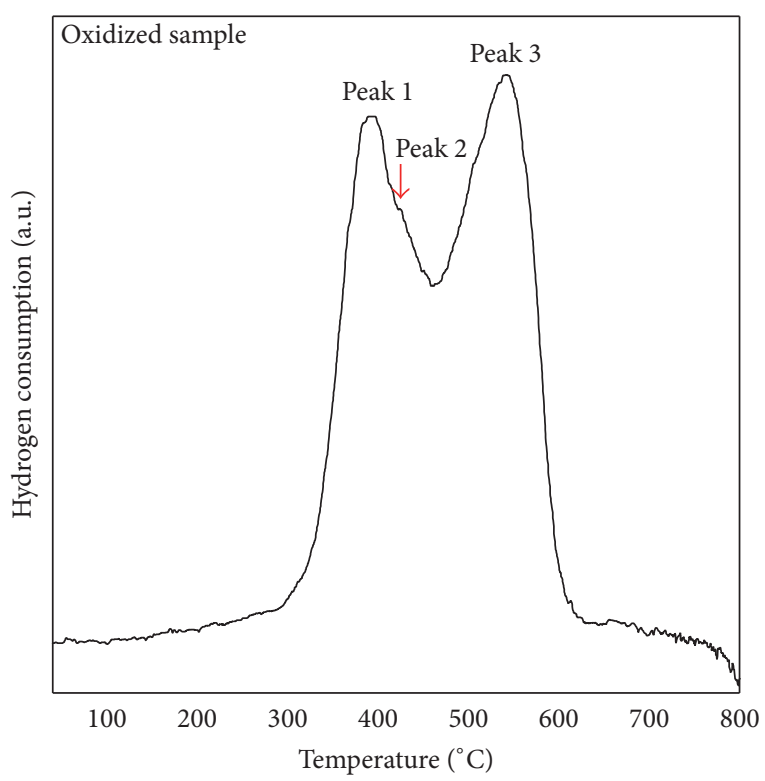

FIGURE 2: Temperature programmed reduction (TPR) carried out in the oxidized sample.

the literature reports different reduction temperatures for iron and the nickel, for example, nickel ferrite and catalysts containing nickel with support interactions [2, 26-28]. In this sense, the coexistence of FeNi alloy and oxides at temperatures around $500^{\circ} \mathrm{C}$ is considered, while the pure alloy can only be obtained at temperatures above $650^{\circ} \mathrm{C}$. This result is clearly heavily dependent on the flow used in the reduction process.

X-ray diffraction of the samples treated for 60 minutes at different temperatures and hydrogen flows are presented in Figure 3. The best results obtained for each set of the samples are shown in this Figure. The reduction process was not satisfactory for the samples treated at $500^{\circ} \mathrm{C}$, even using a flow of $50 \mathrm{~mL} / \mathrm{min}$. The analyses showed the presence of taenite (FeNi-JCPDS 47-1417), awaruite ( $\mathrm{FeNi}_{3}$-JCPDS 380419), iron oxide $\left(\mathrm{Fe}_{3} \mathrm{O}_{4}\right.$-JCPDS 75-0449), and possibly a very small fraction of nickel (Ni-JCPDS 04-0850). For this sample (Figure 3(a)), the structural refinement confirmed that synthesized $\mathrm{FeNi}$ alloy has cubic symmetry, lattice parameters of $3.5845 \AA$, and mean domain size around $17 \mathrm{~nm}$. An isotropic model (pseudo-voigt function \#4) present in the GSAS manual was considered for mean domain size. Additionally, other information about the phase and refinement is presented in Table 1. It is assumed that a reduction with 60 or $70 \mathrm{~mL} / \mathrm{min}$ for this series probably allowed for obtaining the pure alloy.

The pure alloy was observed in the second set of the samples, being treated at $600^{\circ} \mathrm{C}$ with flows of 40 and $50 \mathrm{~mL} / \mathrm{min}$ (Figure 3(b)). The result shown in Figure 3(b) is very important, since relatively good energetic conditions were determined for obtaining the desirable material by the chosen method. Compared with the previous series (as can be seen in Table 1), there was a slight increase in the lattice parameters and a significant increase in the mean domain 


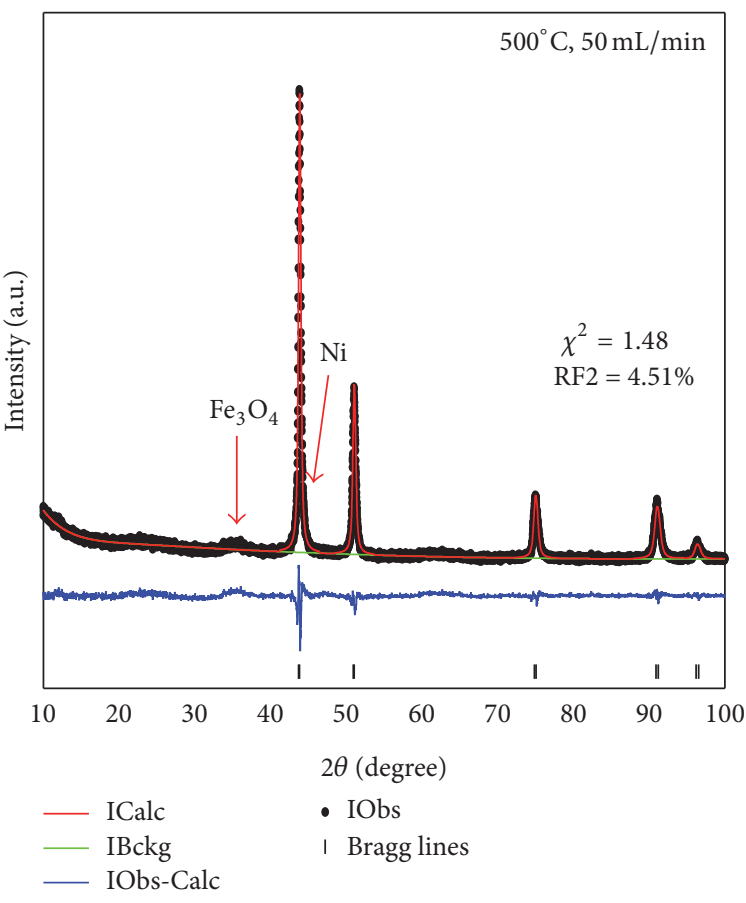

(a)

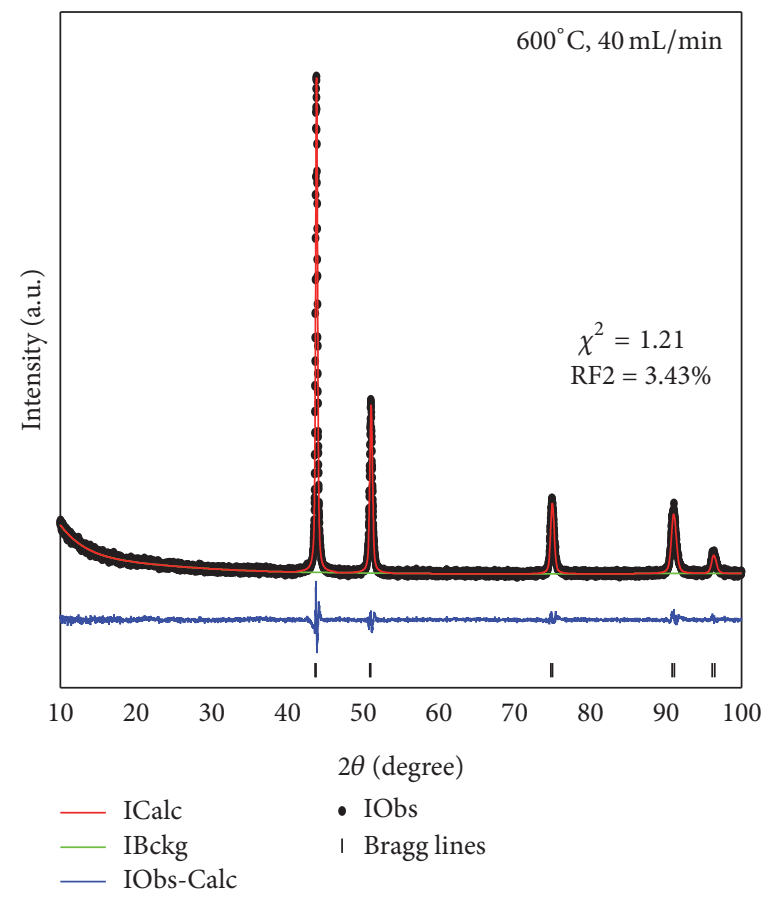

(b)

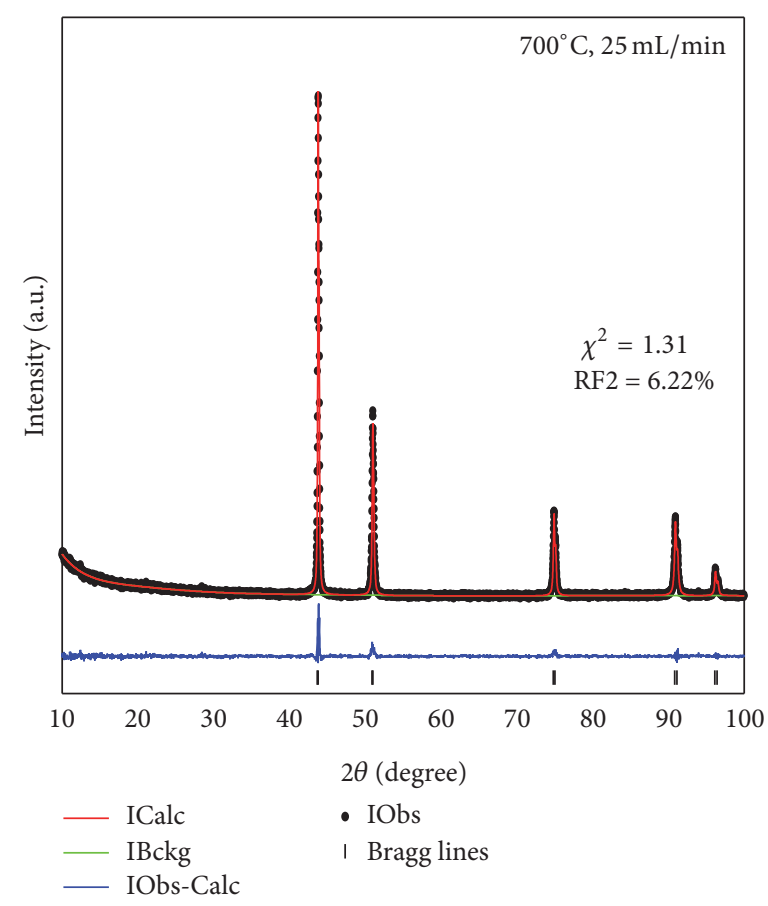

(c)

Figure 3: Rietveld refinement for samples reduced at (a) $500^{\circ} \mathrm{C}, 50 \mathrm{~mL} / \mathrm{min}$; (b) $600^{\circ} \mathrm{C}, 40 \mathrm{~mL} / \mathrm{min}$; and (c) $700^{\circ} \mathrm{C}, 25 \mathrm{~mL} / \mathrm{min}$.

size. Furthermore, this result cooperates with TPR analysis, which shows that a temperature of $600^{\circ} \mathrm{C}$ may be sufficient for alloy formation with a reasonable flow. Another important result related to optimizing the synthesis parameter was obtained in the samples treated at $700^{\circ} \mathrm{C}$. It was observed that a flow of $25 \mathrm{~mL} / \mathrm{min}$ (Figure 3(c)) is enough to form the FeNi alloy for this temperature. As expected (as can be seen in Table 1), an increase in the mean domain size for this temperature was observed.

In 1994, Scorzelli et al. [4] synthesized disordered FeNi alloys in the range of $38-50$ at $\% \mathrm{Ni}$. These samples were obtained by gas evaporation coalescence technique, which 
TABLE 1: Crystallographic and microscopy data of the main samples.

\begin{tabular}{|c|c|c|c|c|}
\hline \multicolumn{5}{|c|}{ Structure information } \\
\hline \multirow{2}{*}{\multicolumn{2}{|c|}{ Molecular formula: $\mathrm{FeNi}$}} & \multirow{2}{*}{\multicolumn{3}{|c|}{$\begin{array}{c}\text { Symmetry: cubic } \\
\text { Space group: Fm-3m }\end{array}$}} \\
\hline & & & & \\
\hline \multicolumn{5}{|c|}{ Refinement and microscopy information } \\
\hline Temperature $\left({ }^{\circ} \mathrm{C}\right)$ & $\mathrm{H}_{2}(\mathrm{~mL} / \mathrm{min})$ & Lattice parameters $(\AA)$ & XRD MDS* (nm) & TEM PS* (nm) \\
\hline 500 & 50 & 3.5845 & 17 & - \\
\hline \multirow{2}{*}{600} & 40 & 3.5866 & 29 & - \\
\hline & 50 & 3.5868 & 31 & 10 to $40 \mathrm{~nm}$ \\
\hline \multirow{4}{*}{700} & 25 & 3.5872 & 54 & - \\
\hline & 30 & 3.5878 & 36 & - \\
\hline & 40 & 3.5873 & 53 & - \\
\hline & 50 & 3.5869 & 37 & 25 to $75 \mathrm{~nm}$ \\
\hline
\end{tabular}

${ }^{*}$ MDS.: mean domain size and PS: particle size.

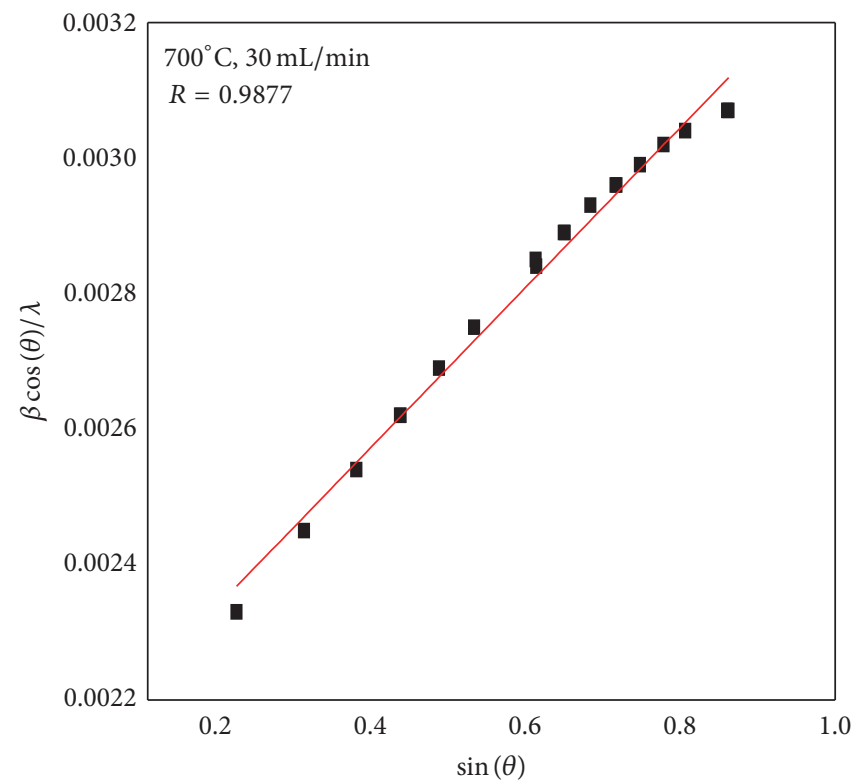

(a)

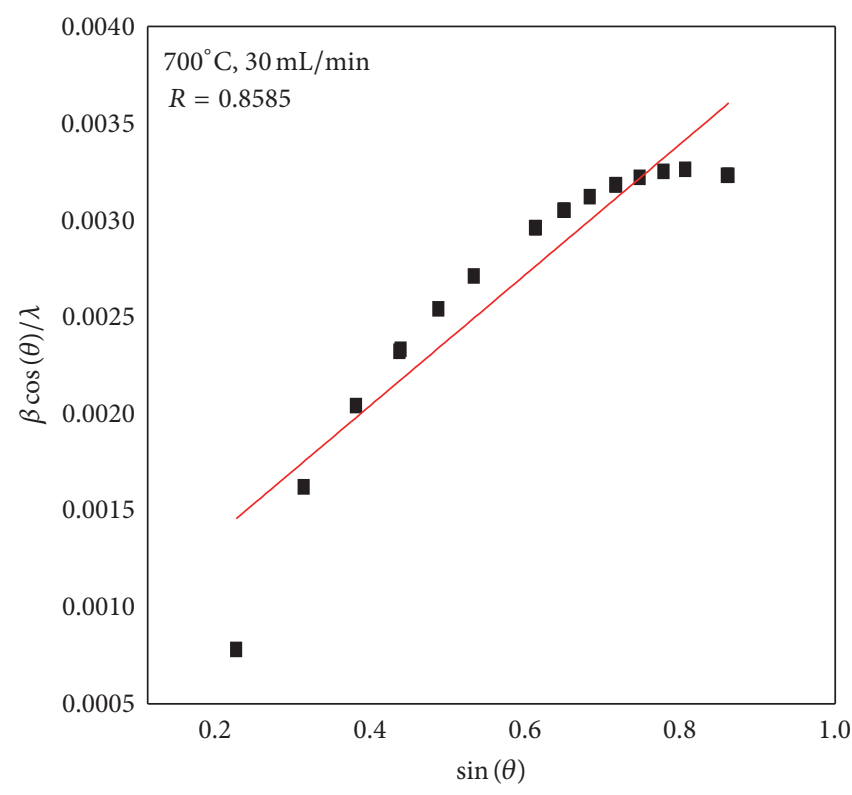

(b)

FIgURE 4: Williamson-Hall plots for samples reduced (a) with and (b) without rotation.

showed the same crystallographic characteristics of the solids synthesized in this work. A difference of not more than $0.16 \%$ was calculated for the lattice parameters. In addition, the authors revealed a difficulty to obtain the alloy at $500^{\circ} \mathrm{C}$, even with long treatments due to low atomic diffusion. However, as previously mentioned, it is believed that a FeNi alloy can be obtained by the proteic Sol-Gel method, with hydrogen flows above $50 \mathrm{~mL} / \mathrm{min}$.

The mechanical milling process conducted by Qin et al. [1], Djekoun et al. [6], and Guittoum et al. [7] also allowed for obtaining the FeNi alloy. Qin et al. synthesized alloys with concentrations of $30,45,55$, and 65 at $\% \mathrm{Ni}$, respectively, from oxides. In this case, the samples showed crystallite sizes in the range of 29 to $39.5 \mathrm{~nm}$ when reduced with hydrogen flow at $500^{\circ} \mathrm{C}$ for 1 hour and after being annealed in situ at $600^{\circ} \mathrm{C}$ for 20 minutes. The results were very close to those found in this study for the samples reduced at $600^{\circ} \mathrm{C}$ (Table 1). Djekoun et al. also reported having obtained FeNi alloy from pure metals. In this study, the presence of taenite was estimated by X-ray diffraction and it was confirmed by Mössbauer spectroscopy. Guittoum et al. reported having obtained the ordered alloy $\left(\mathrm{Fe}_{50} \mathrm{Ni}_{50}\right)$, also from pure metals (50 at $\%$ metal), with lattice parameters in the order of $3.5953 \AA$ and mean crystallite size of $12.9 \mathrm{~nm}$. In comparing our results with others reported in the literature, the viability of the synthesis method employed was confirmed.

The effect of a rotation system during synthesis in the microstrain and particle size homogeneity was observed on samples reduced at $700^{\circ} \mathrm{C}$ with hydrogen flow of $30 \mathrm{~mL} / \mathrm{min}$ (Figure 4). Williamson-Hall plot showed better linear fitting $(R=0.9877)$ for the sample obtained with rotation (Figure 4(a)) when compared with the sample obtained without rotation (Figure 4(b)). Additionally, the microstrain value was higher for the solid without rotation. This result 


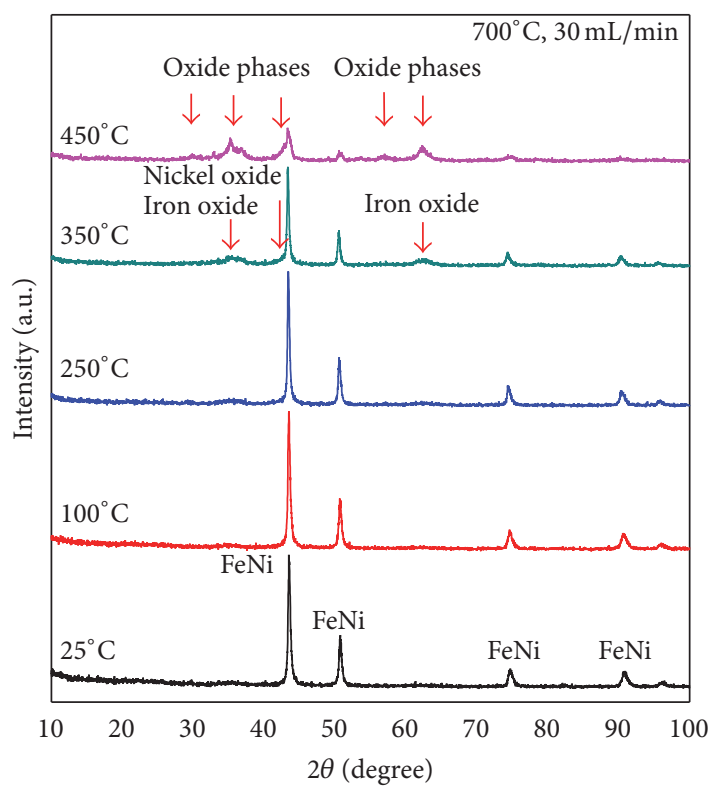

FIGURE 5: Thermal stability analysis against oxidizing atmosphere.

reinforces the importance of the methodology used, which was previously reported by Braga et al. [15] working with FeCo alloy.

For finalizing structural characterization, diffractograms obtained at $25,100,250,350$, and $450^{\circ} \mathrm{C}$ under air atmosphere are presented in Figure 5 in order to observe $\mathrm{FeNi}$ alloy stability against the oxidizing atmosphere. Using a high temperature oven coupled to the diffractometer, it was observed that the alloy remained stable in temperatures of 25,100 , and $250^{\circ} \mathrm{C}$. However, at $350^{\circ} \mathrm{C}$ it is possible to verify the beginning of phase segregation and the presence of iron and nickel oxides. Also, there is a large concentration of these oxides at $450^{\circ} \mathrm{C}$. These results indicate that the FeNi alloy is quite stable up to $250^{\circ} \mathrm{C}$. It is important to highlight that stability characterization against oxidation is rarely mentioned in the literature.

Sample morphology reduced at $50 \mathrm{~mL} / \mathrm{min}$ and analyzed by SEM-FEG is presented in Figure 6. The sample reduced at $500^{\circ} \mathrm{C}$ (Figure $6(\mathrm{a})$ ) shows agglomerates constituted by spherical grains ranging in size from 20 to $50 \mathrm{~nm}$. For the sample reduced at $600^{\circ} \mathrm{C}$ (Figure 6(b)), a reduction on homogeneity of the grain size was observed and varies between 50 and $150 \mathrm{~nm}$. Furthermore, the sample reduced at $700^{\circ} \mathrm{C}$ (Figure 6(c)) shows greater homogeneity when compared with other samples, with size ranging from 50 to $300 \mathrm{~nm}$. The obtained morphology is similar to those reported by Qin et al. [1] and Xu et al. [8] in samples synthesized by mechanochemical process and hydrazine reduction, respectively. However, while Qin et al. reported grain sizes around $200 \mathrm{~nm}$, Xu et al. reported sizes ranging between 50 and $80 \mathrm{~nm}$. On the other hand, the morphology is quite different from that observed by Djekoun et al. [6] and Guittoum et al. [7] prepared by mechanical alloying, where both authors observed a ductile and lamellar structure. This shows that the morphology is strongly dependent on the synthesis conditions.
TABLE 2: Magnetic properties of alloy synthesized with $50 \mathrm{~mL} / \mathrm{min}$ and treated at 600 and $700^{\circ} \mathrm{C}$.

\begin{tabular}{lcc}
\hline \multicolumn{3}{c}{ Mössbauer spectroscopy } \\
\hline \multicolumn{3}{c}{$600^{\circ} \mathrm{C}-50 \mathrm{~mL} / \mathrm{min}\left(\mathrm{H}_{2}\right)$} \\
Sypglet & Sextet \\
Isomer shift & - & $31.49 \mathrm{~T}$ \\
Quadrupole splitting & $-0.120 \mathrm{~mm} / \mathrm{s}$ & $-0.078 \mathrm{~mm} / \mathrm{s}$ \\
Area & - & $-0.007 \mathrm{~mm} / \mathrm{s}$ \\
\hline \multicolumn{3}{c}{ Vibrating sample magnetometry } \\
\hline & $600^{\circ} \mathrm{C}-$ & $98.0 \%$ \\
\hline Magnetization & $50 \mathrm{~mL} / \mathrm{min}\left(\mathrm{H}_{2}\right)$ & $50 \mathrm{~mL} / \mathrm{min}\left(\mathrm{H}_{2}\right)$ \\
saturation & $113.35 \mathrm{emu} / \mathrm{g}$ & $141.33 \mathrm{emu} / \mathrm{g}$ \\
Remnant & $21.03 \mathrm{emu} / \mathrm{g}$ & $19.09 \mathrm{emu} / \mathrm{g}$ \\
magnetization & $262.77 \mathrm{Oe}$ & $188.08 \mathrm{Oe}$ \\
Coercivity field &
\end{tabular}

TEM was employed in the samples reduced at a flow of $50 \mathrm{~mL} / \mathrm{min}$ for more precision on the particle size, as shown in Figure 7. The sample treated at $600^{\circ} \mathrm{C}$ (Figure 7(a)) presents spherical particles with sizes varying from 10 to $40 \mathrm{~nm}$, while the sample treated at $700^{\circ} \mathrm{C}$ (Figure $7(\mathrm{~b})$ ) shows particle sizes in the range of 20 to $75 \mathrm{~nm}$. Suh et al. [5] synthesized FeNi alloy nanoparticles at several evaporation temperatures by hydrogen reduction of metal chlorites. The authors mentioned that TEM revealed particles forming chains with diameters of $74 \mathrm{~nm}$ and $109 \mathrm{~nm}$ for reaction temperatures of 800 and $900^{\circ} \mathrm{C}$, respectively. The particle sizes obtained in this work are in accordance with Suh, although a chainshaped structure was not observed. The results from XRD and TEM for the samples reduced at 600 and $700^{\circ} \mathrm{C}$ with flow of $50 \mathrm{~mL} / \mathrm{min}$ can be compared in Table 1. It is considered that there was reasonably good approximation between XRD and TEM, although TEM provides more accurate measurements.

In order to obtain information related to the iron chemical environment, Mössbauer spectroscopy was performed for the sample reduced at $600^{\circ} \mathrm{C}$ with $50 \mathrm{~mL} / \mathrm{min}$, supplementing the results obtained by XRD. The spectrum and data can be seen in Figure 8 and Table 2, respectively. In the spectrum, the presence of a singlet is assigned to a fraction of $\mathrm{FeNi}$ alloy with low concentration of nickel, being around 30 at\%. This is related to the small nanoparticles, probably in the superparamagnetic state $[6,7,29]$. Also, this presence of small particles is confirmed by XRD and TEM. The sextet had a hyperfine magnetic field of $31.49 \mathrm{~T}$ with a concentration around $98 \%$; this is related to disordered FeNi ferromagnetic phase, as noted in the XRD results [6, 7]. Contributions relating to nickel ferrite were not detected. These results are in accordance with XRD analysis, which showed the formation of a pure FeNi alloy.

In addition to the Mössbauer spectroscopy, magnetic hysteresis loop of the samples reduced at 600 and $700^{\circ} \mathrm{C}$ using a flow of $50 \mathrm{~mL} / \mathrm{min}$ was determined by VSM, as shown in Figure 9. Moreover, Table 2 summarizes the magnetic properties. For the sample reduced at $600^{\circ} \mathrm{C}$ (Figure 9(a)), it was observed that the saturation magnetization occurred in the 


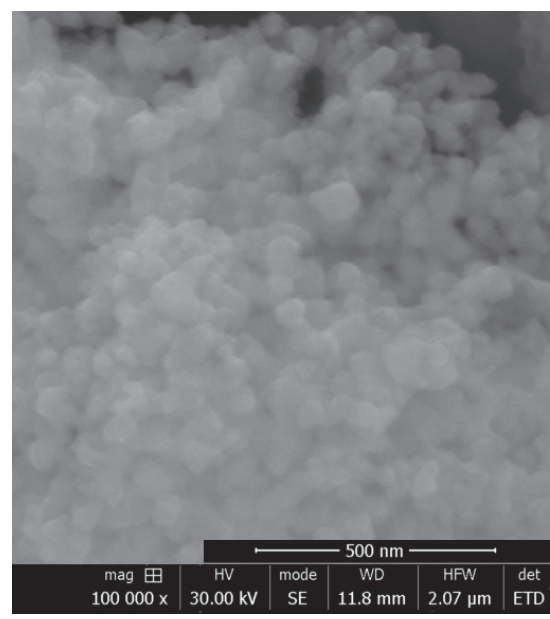

(a)

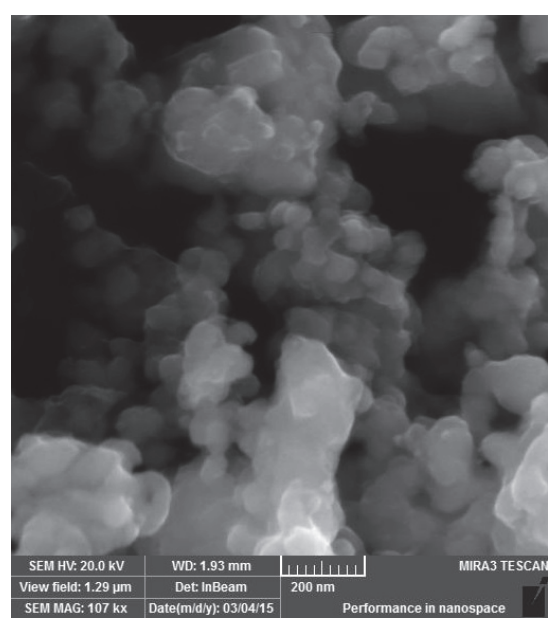

(b)

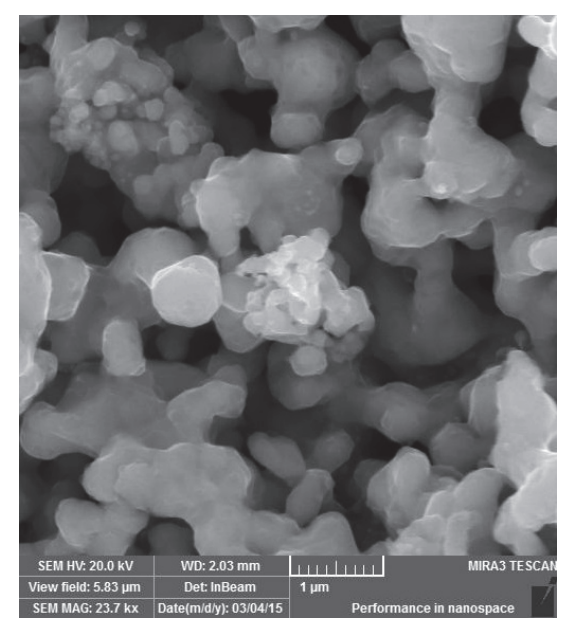

(c)

FIGURE 6: SEM-FEG analysis for the samples reduced with flow of $50 \mathrm{~mL} / \mathrm{min}$ : (a) $500^{\circ} \mathrm{C}$, (b) $600^{\circ} \mathrm{C}$, and (c) $700^{\circ} \mathrm{C}$.

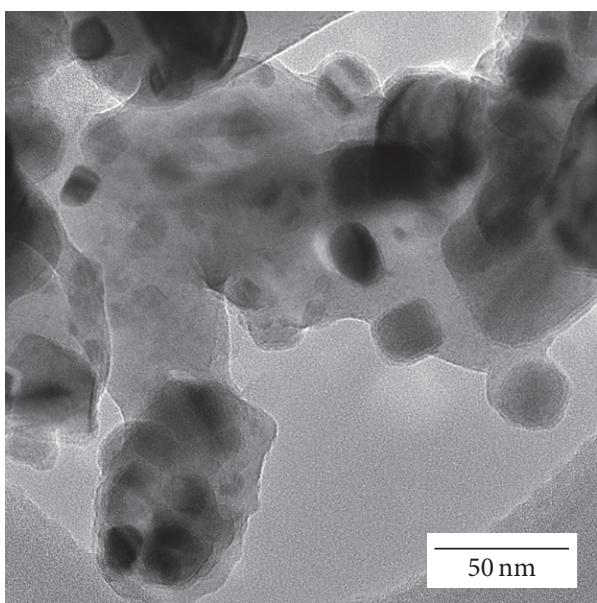

(a)

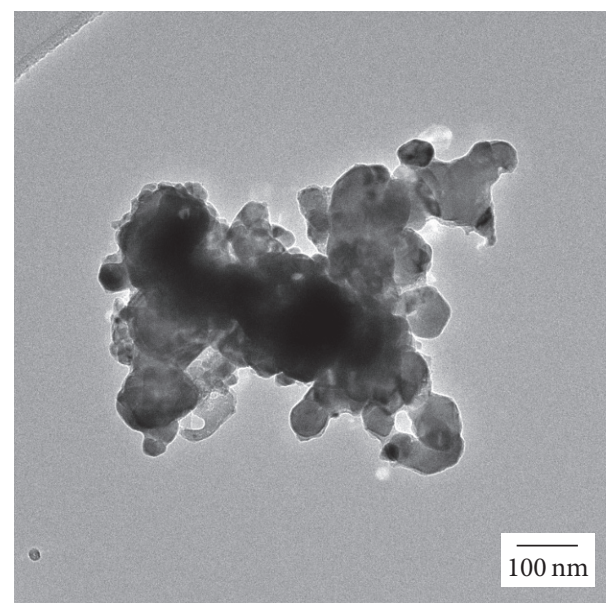

(b)

FIgURE 7: TEM analysis for the samples reduced with flow of $50 \mathrm{~mL} / \mathrm{min}$ : (a) $600^{\circ} \mathrm{C}$ and (b) $700^{\circ} \mathrm{C}$.

region of 7 to $12 \mathrm{kOe}$, with a value of $113.35 \mathrm{emu} / \mathrm{g}$. Remnant magnetization and coercivity values were $21.03 \mathrm{emu} / \mathrm{g}$ and 262.77 Oe, respectively. This result is close to that related by Guittoum et al. [7] for a sample processed with $50 \mathrm{~h}$ of milling, and it is considered a behavior of magnetically soft material. Comparatively, the sample reduced at $700^{\circ} \mathrm{C}$ (Figure 9(b)) presented an increase in the saturation magnetization, with a value of $141.33 \mathrm{emu} / \mathrm{g}$ occurring in the region of 9 to $12 \mathrm{kOe}$. On the other hand, both remnant magnetization and coercivity showed a reduction with values of $19.09 \mathrm{emu} / \mathrm{g}$ and $188.08 \mathrm{Oe}$, respectively. This fact indicates a more magnetically soft material for the second sample, but the samples cannot be considered a superparamagnetic material.

\section{Conclusions}

Nanostructured FeNi alloys were synthesized via proteic SolGel route using bovine gelatin as chelating agent. Optimized conditions for temperature and hydrogen flow for obtaining the FeNi alloys through this method were also determined. The specific temperatures are consistent with those found in phase diagrams, reinforcing gamma phase formation. Furthermore, the material proved to be thermally stable up to $250^{\circ} \mathrm{C}$. The morphology revealed the presence of relatively spherical grains and particles in the range of 10$40 \mathrm{~nm}$. Confirmation of obtaining disordered FeNi alloy was performed by magnetic measurements, where the behavior of magnetically soft materials was also shown.

\section{Competing Interests}

The authors declare that they have no competing interests.

\section{Acknowledgments}

The authors would like to thank Brazilian funding agencies CNPq (processo PNPD/CNPq 561093/2010-5) and CAPES 


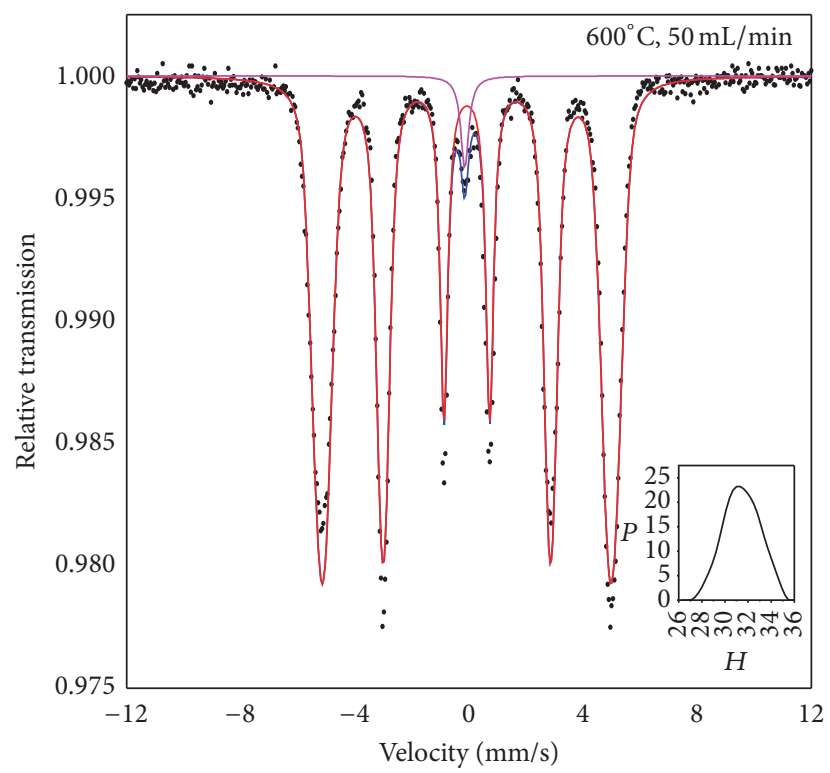

FIGURE 8: Mössbauer spectroscopy of sample reduced at $600^{\circ} \mathrm{C}$ with flow of $50 \mathrm{~mL} / \mathrm{min}$.

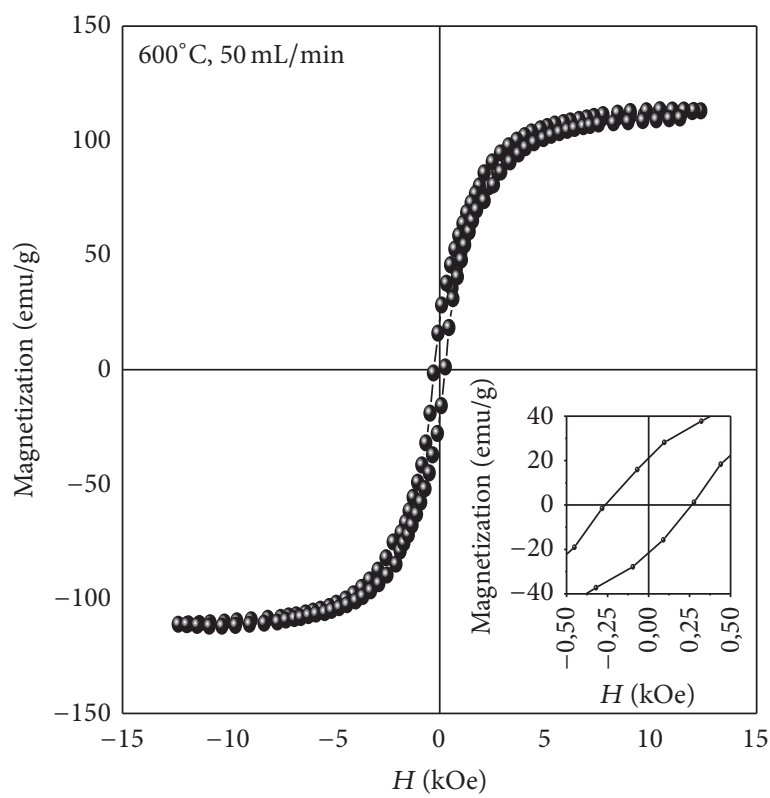

(a)

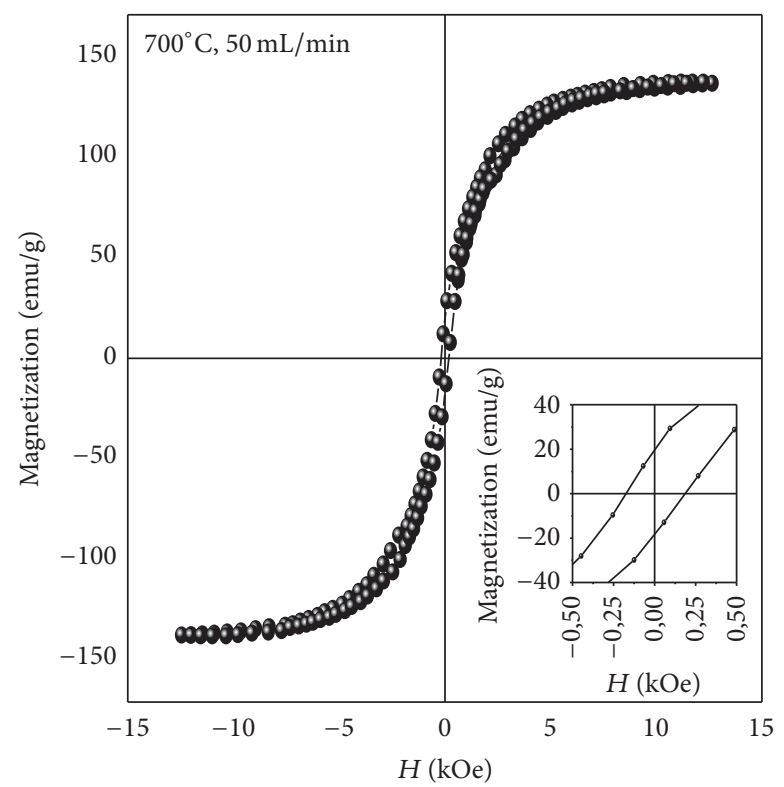

(b)

Figure 9: Hysteresis of samples reduced with flow of $50 \mathrm{~mL} / \mathrm{min}$ : (a) $600^{\circ} \mathrm{C}$ and (b) $700^{\circ} \mathrm{C}$.

for financial support and, also, Gelita Company for providing the edible gelatin and the Laboratório Nacional de Nanotecnologia (LNNano/CNPEM) for providing the equipment and technical support for the experiments involving transmission electron microscopy (TEM).

\section{References}

[1] X. Y. Qin, J. G. Kim, and J. S. Lee, "Synthesis and magnetic properties of nanostructured $\gamma$-Ni-Fe alloys," Nanostructured Materials, vol. 11, no. 2, pp. 259-270, 1999.
[2] R. da Paz Fiuza, M. A. da Silva, and J. S. Boaventura, "Development of $\mathrm{Fe}-\mathrm{Ni} / \mathrm{YSZ}-\mathrm{GDC}$ electro-catalysts for application as SOFC anodes: XRD and TPR characterization and evaluation in ethanol steam reforming reaction," International Journal of Hydrogen Energy, vol. 35, no. 20, pp. 11216-11228, 2010.

[3] C.-F. Zhang, Y.-L. Yao, Y.-L. Zhang, and J. Zhan, "Preparation of ultra-fine fibrous $\mathrm{Fe}-\mathrm{Ni}$ alloy powder by coordinated coprecipitation-direct reduction process," Transactions of Nonferrous Metals Society of China, vol. 22, no. 12, pp. 2972-2978, 2012.

[4] R. B. Scorzelli, E. Galvão da Silva, C. Kaito, Y. Saito, M. McElfresh, and M. Elmassalami, "Mössbauer spectroscopy, 
X-ray diffraction and magnetic measurements of iron-nickel ultrafine particles," Hyperfine Interactions, vol. 94, no. 1, pp. 2337-2342, 1994.

[5] Y. J. Suh, H. D. Jang, H. Chang, W. B. Kim, and H. C. Kim, "Sizecontrolled synthesis of $\mathrm{Fe}-\mathrm{Ni}$ alloy nanoparticles by hydrogen reduction of metal chlorides," Powder Technology, vol. 161, no. 3, pp. 196-201, 2006.

[6] A. Djekoun, B. Bouzabata, A. Otmani, and J. M. Greneche, "Xray diffraction and Mössbauer studies of nanocrystalline $\mathrm{Fe}-\mathrm{Ni}$ alloys prepared by mechanical alloying," Catalysis Today, vol. 89, no. 3, pp. 319-323, 2004.

[7] A. Guittoum, A. Layadi, A. Bourzami et al., "X-ray diffraction, microstructure, Mössbauer and magnetization studies of nanostructured $\mathrm{Fe}_{50} \mathrm{Ni}_{50}$ alloy prepared by mechanical alloying," Journal of Magnetism and Magnetic Materials, vol. 320, no. 7, pp. 1385-1392, 2008.

[8] Z. Xu, C. Jin, A. Xia, J. Zhang, and G. Zhu, "Structural and magnetic properties of nanocrystalline nickel-rich $\mathrm{Fe}-\mathrm{Ni}$ alloy powders prepared via hydrazine reduction," Journal of Magnetism and Magnetic Materials, vol. 336, pp. 14-19, 2013.

[9] Y. Jiang, S. Yang, Z. Hua, and H. Huang, "Sol-gel autocombustion synthesis of metals and metal alloys," Angewandte Chemie-International Edition, vol. 48, no. 45, pp. 8529-8531, 2009.

[10] M. P. Pechini, Patent. Method of preparing lead and alkaline earth titanates and niobates and coating method using the same to form a capacitor, United States Patent Office, 3330697, July, 1967.

[11] C. J. Brinker and G. W. Scherer, Sol-Gel Science: The Physics and Chemistry of Sol-Gel Processing, Academic press, New York, NY, USA, 1990.

[12] M. Kakihana, "Invited review 'sol-gel' preparation of high temperature superconducting oxides," Journal of Sol-Gel Science and Technology, vol. 6, no. 1, pp. 7-55, 1996.

[13] B. L. Cushing, V. L. Kolesnichenko, and C. J. O'Connor, "Recent advances in the liquid-phase syntheses of inorganic nanoparticles," Chemical Reviews, vol.104, no. 9, pp. 3893-3946, 2004.

[14] V. K. S. Soares, M. D. A. Gomes, R. S. Da Silva, Z. S. MacEdo, and C. H. Hayasi, "Production of $\mathrm{Al}_{2} \mathrm{O}_{3}$ nanoparticles employing mature coconut water (dried coconut)," Cerâmica, vol. 59, no. 349, pp. 160-164, 2013.

[15] T. P. Braga, D. F. Dias, M. F. de Sousa, J. M. Soares, and J. M. Sasaki, "Synthesis of air stable FeCo alloy nanocrystallite by proteic sol-gel method using a rotary oven," Journal of Alloys and Compounds, vol. 622, pp. 408-417, 2015.

[16] N. A. S. Nogueira, V. H. S. Utuni, Y. C. Silva et al., "X-Ray diffraction and Mössbauer studies on superparamagnetic nickel ferrite $\left(\mathrm{NiFe}_{2} \mathrm{O}_{4}\right)$ obtained by the proteic Sol-Gel method," Materials Chemistry and Physics, vol. 163, pp. 402-406, 2015.

[17] C. T. Meneses, W. H. Flores, F. Garcia, and J. M. Sasaki, "A simple route to the synthesis of high-quality $\mathrm{NiO}$ nanoparticles," Journal of Nanoparticle Research, vol. 9, no. 3, pp. 501-505, 2007.

[18] JCPDS-ICCD Database, The International Center of Diffraction Data, version 2.4, 2003.

[19] A. C. Larson and R. B. Von Dreele, "General Structure Analysis System (GSAS)," Los Alamos National Laboratory Report LAUR 86-748, Los Alamos National Laboratory, 2004.

[20] B. H. Toby, "EXPGUI, a graphical user interface for GSAS," Journal of Applied Crystallography, vol. 34, no. 2, pp. 210-213, 2001.
[21] R. A. Brand, Software. Normos Mössbauer Fit Program, Duisburg University, 1995.

[22] G. Grosse, "Software," PC-Mos II version 1.0, 1993.

[23] L. V. Azároff, Book. Elements of X-Ray Crystallography, McGraw-Hill Book Company, 1st edition, 1968.

[24] B. D. Cullity, Introduction to Magnetic Materials, AddisonWesley, New York, NY, USA, 1st edition, 1972.

[25] C. Bernal, A. B. Couto, S. T. Breviglieri, and É. T. G. Cavalheiro, "Influência de alguns parâmetros experimentais nos resultados de análises calorimétricas diferenciais-DSC," Química Nova, vol. 25, no. 5, pp. 849-855, 2002.

[26] E. Manova, T. Tsoncheva, D. Paneva et al., "Synthesis, characterization and catalytic properties of nanodimensional nickel ferrite/silica composites," Applied Catalysis A: General, vol. 317, no. 1, pp. 34-42, 2007.

[27] M. Afzal, C. R. Theocharis, and S. Karim, "Temperature programmed reduction of silica supported nickel catalysts," Colloid \& Polymer Science, vol. 271, no. 11, pp. 1100-1105, 1993.

[28] J. C. Tristão, F. C. Moura, R. M. Lago, and K. Sapag, "Sistema RTP: uma técnica poderosa para o monitoramento da formação de nanotubos de carbono durante o processo por deposição de vapor químico," Química Nova, vol. 33, no. 6, pp. 1379-1383, 2010.

[29] H. N. Ok and M. S. Han, "Mössbauer studies on the superparamagnetic behavior of 69-31 at.\% FeNi fine particles," Journal of Applied Physics, vol. 44, no. 4, pp. 1932-1933, 1973. 

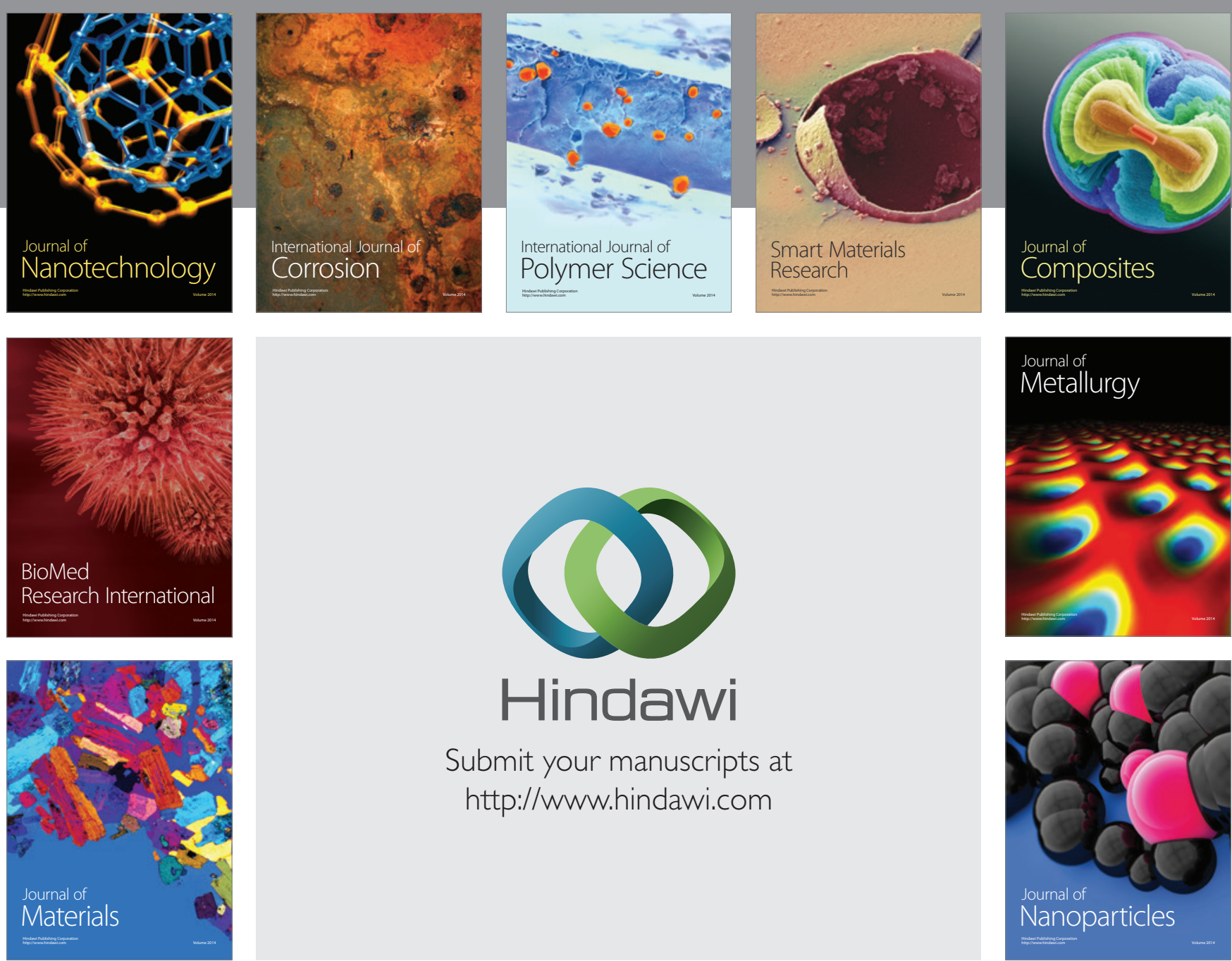

\section{Hindawi}

Submit your manuscripts at

http://www.hindawi.com

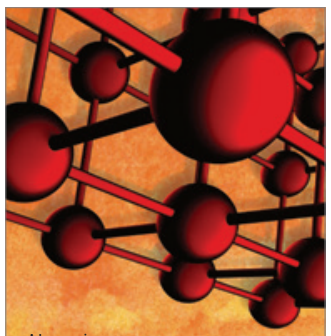

Materials Science and Engineering
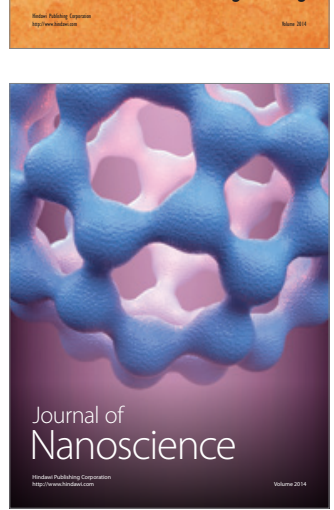
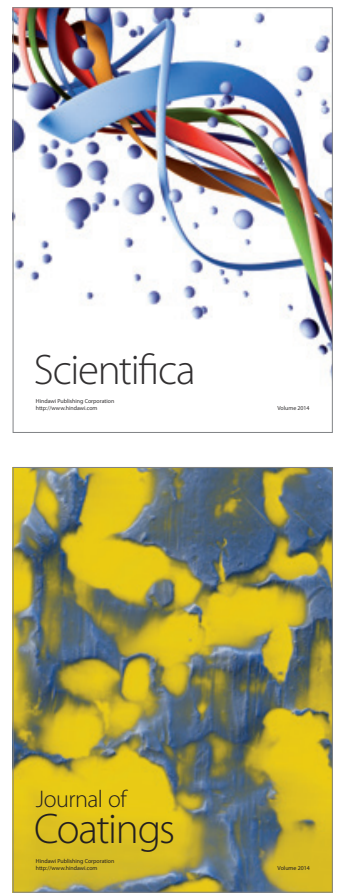
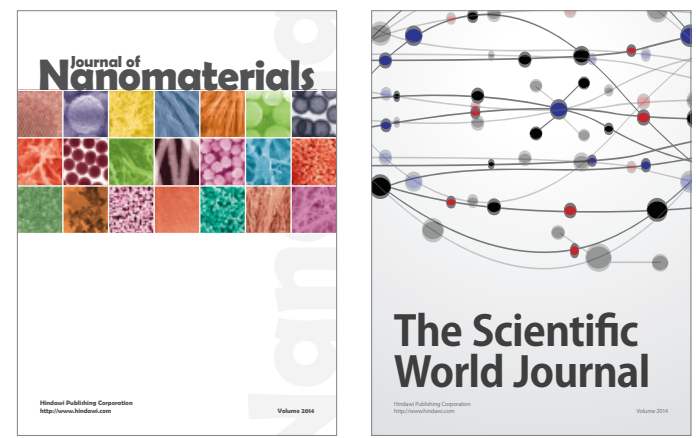

The Scientific World Journal
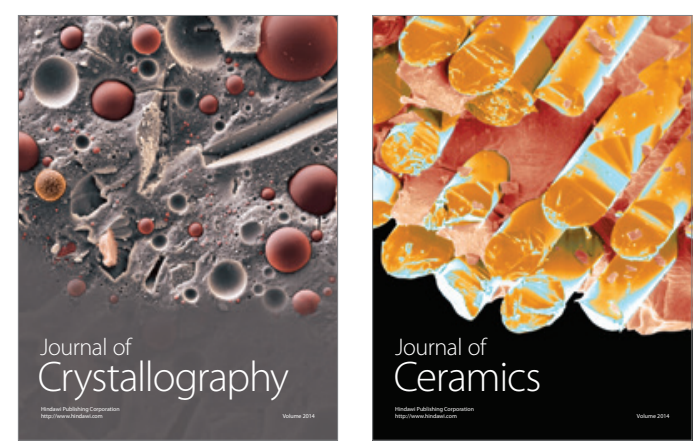
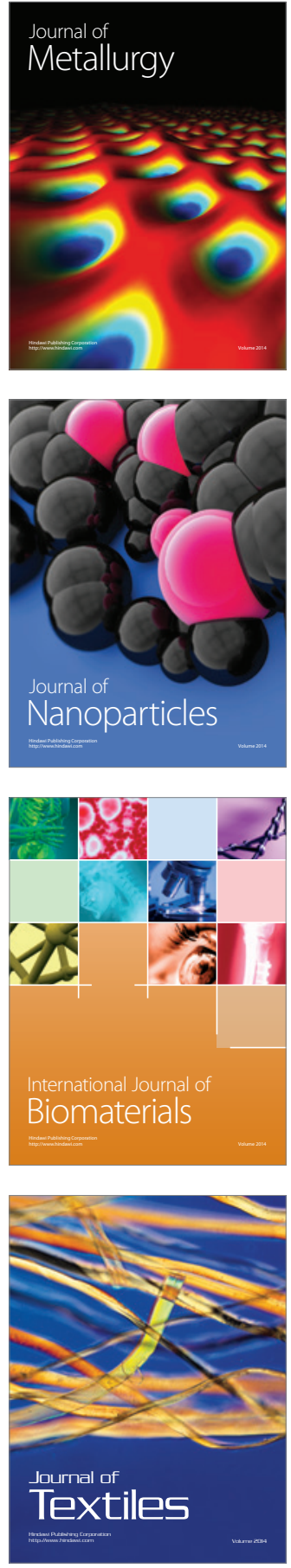